\title{
PEMERINTAHAN DAERAH DALAM SISTEM OTONOMI
}

\author{
JOHANSYAH \\ Fakultas Hukum Universitas Palembang \\ johansyah@unpal.ac.id \\ ABSTRACT
}

Local government system has connection to regional autonomy, which has been applied in Indonesia. Then before, all systems are centralized administration, then after the implementation of regional autonomy expected the region could set its own regional government of live by optimizing the existing pontential of the region. Nevertheless, there are some things remain regulated by the central government as the country's financial affairs, religion, foreign affairs, and others, Also, local government system actually is one form of government that is efficient and effective. Because in general, the central government may not take care of all the country's problems are so complex. On the other hand, local governments as well as the training ground and the development of democracy in a counntry life.

\section{Keywords: Regional Government; Autonomous System; State Administration System}

\section{ABSTRAK}

Sistem pemerintahan daerah berhubungan erat dengan otonomi daerah yang saat ini telah diterapkan di Indonesia. Jika sebelumnya semua sistem pemerintahan bersifat terpusat atau sentralisasi, maka setelah diterapkannya otonomi daerah diharapkan daerah bisa mengatur kehidupan pemerintahan daerah sendiri dengan cara mengoptimalkan potensi daerah yang ada. Meskipun demikian, terdapat beberapa hal tetap diatur oleh pemerintah pusat seperti urusan keuangan negara, agama, hubungan luar negeri, dan lain-lain. Sistem pemerintahan daerah juga sebetulnya merupakan salah satu wujud penyelenggaraan pemerintahan yang efisien dan efektif. Sebab pada umumnya tidak mungkin pemerintah pusat mengurusi semua permasalahan negara yang begitu kompleks. Disisi lain, pemerintahan daerah juga sebagai training ground dan pengembangan demokrasi dalam sebuah kehidupan negara.

\section{Kata Kunci: Pemerintahan Daerah; Sistem Otonomi; Sistem Ketatanegaraan}

\section{PENDAHULUAN}

\section{A. Latar Belakang}

Secara konstitusional Negara Republik Indonesia merupakan negara kesatuan, hal ini ditegaskan oleh pasal 1 ayat (1) UUD. 1945 menyatakan bahwa Negara Indonesia adalah Negara Kesatuan yang berbentuk Republik.

Ditinjau dari segi susunannya, Negara kesatuan adalah negara yang tidak terdiri dari beberapa negara, seperti halnya dalam negara federal, melainkan negara itu sifatnya tunggal, artinya hanya ada satu negara tidak ada negara didalam negara. Dengan demikian didalam negara kesatuan wewenang eksekutif tertinggi dipusatkan dalam satu badan eksekutif nasional/pusat. Kekuasaan terletak pada Pemerintah Pusat dan tidak pada pemerintah daerah. Pemerintah Pusat mempunyai wewenang untuk menyerahkan sebagian kekuasaannya kepada daerah berdasarkan hak otonomi (negara kesatuan dengan sistim desentralisasi) tetapi pada tahap terakhir kekuasaan tertinggi tetap ditangan pemerintah pusat. Jadi kedaulatannya, baik kedaulatan kedalam maupun keluar, sepenuhnya terletak pada Pemerintah Pusat. Yang menjadi hakekat negara kesatuan adalah bahwa kedaulatannya tidak terbagi atau dengan perkataan lain kekuasaan pemerintah pusat tidak dibatasi oleh karena konstitusi negara kesatuan tidak mengakui badan eksekutif lain, selain dari badan eksekutif pusat.

Adanya kewenangan untuk membuat peraturan bagi daerahnya sendiri tidaklah berarti bahwa pemerintah daerah itu berdaulat sebab pengawasan dan kekuasaan 
tertinggi tetap terletak pada pemerintah pusat.

Lebih lanjut ada dua ciri mutlak yang melekat pada negara kesatuan, yaitu :

Adanya Supremasi dari Dewan Perwakilan Rakyat

Tidak adanya badan-badan yang berdaulat ${ }^{1}$.

Jadi didalam negara kesatuan hanya ada satu pemerintah pusat yaitu Pemerintah Pusat yang pada tingkat terakhir dan tertinggi dapat memutuskan segala sesuatu dalam negara tersebut ${ }^{2}$.

Secara teoritis negara kesatuan dapat dibedakan kedalam dua azas yaitu :

Negara kesatuan dengan sistem sentralisasi yaitu segala sesuatu dalam negara itu langsung diatur dan diurus oleh pemerintah pusat sedang pemerintah daerah tinggal melaksanakannya.

Negara kesatuan dengan sistem desentralisasi yaitu kepada daerah diberikan kesempatan dan kekuasaan untuk mengatur dan mengurus rumah tangganya sendiri.

Negara kesatuan yang yang berazas desentralisasi berarti yang memegang kekuasan tertinggi atas segenap urusan negara lain Pemerintah Pusat (Central Government). Dalam suatu negara kesatuan terdapat azas bahwa segenap urusan-urusan negara ini tidak dibagi antara pemerintah pusat (Central Government) sedemikian rupa, sehingga urusan-urusan negara dalam negara kesatuan ini tetap merupakan suatu kebulatan (eenheid) dan bahwa memegang kekuasaan tertinggi dinegara itu adalah pemerintah pusat. Ini berarti dalam negara kesatuan yang di Sentralisasikan, Pemerintah Pusat tetap mempunyai hak untuk mengawasi daerah-daerah otonom yaitu daerah yang berhak dan berkewajiban mengatur dan mengurus rumah tangganya sendiri $^{3}$

\footnotetext{
${ }^{1}$ Meriam Budiarjo. Dasar-Dasar Ilmu

Politik. PT. Gramedia. Jakarta. 1989. Hal. 140

2. Abu Daud Busroh. Ilmu Negara. Bumi

Aksara. Jakarta. 1990. Hal. 64.

3 . Solly Lubis. Pergeseran Garis Politik

Dan Perundang-Undangan Mengenai Pemerintah

Daearh. Alumni Bandung. 1987. Hal. 16.
}

Adapun penerapan azas desentralisasi secara teoritis didasarkan atas pertimbangan sebagai berikut :

Dilihat dari sudut politik desentralisasi bertujuan menghindarkan penumpukan atau konsentralisasi kekuasaan di satu pihak saja yang pada akhirnya dapat menimbulkan tirani atau diktator.

Dalam bidang politik penyelenggaraan desentralisasi dianggap sebagai tindakan pendemokrasian, untuk menarik rakyat ikut serta dalam mempergunakan hak-hak demokrasi.

Dari segi tehnik organisatoris alasan mengadakan pemerintahan daerah (desentralisasi) adalah semata-mata untuk mencapai suatu pemerintah yang efektif dan efisien. Apa yang dianggap layak untuk diurus oleh pemerintah

setempat pengurusnya diserahkan kepada daerah. Hal-hal yang lebih tepat

ditangani pemerintah pusat tetap diurus oleh pemerintah pusat.

Dari sudut kultural, desentralisasi perlu diadakan, supaya perhatian dapat sepenuhnya kepada kekhususan suatu daerah, seperti ekonomi, watak kebudayaan atau latar belakang sejarahnya.

Dari sudut kepentingan ekonomi, desentralisasi diperlukan karena pemerintah daerah dapat lebih banyak dan secara membantu pembangunan di daerahnya tersebut. ${ }^{4}$

Alasan lain yang mendasari penerapan azas desentralisasi adalah :

Demi terciptanya efektifitas pemerintah.

Demi terlaksananya demokrasi ditingkat bawah (Grassroots Democrasy).

Pelaksanaan desentralisasi akan membawa efektifitas dalam pemerintah sebab pada umumnya wilayah suatu negara terdiri dari berbagai satuan daerah yang masing-masing memiliki sifat-sifat tersendiri yang

\footnotetext{
4. The liang Gie. Pertumbuhan

Pemerintahan Daerah di Negara Republik Indonesia

Gunung Agung, Jakarta, 1968, h. 35-41
} 
disebabkan oleh faktor-faktor geografis, kebudayaan, pendidikan dan lain-lain'.

Melihat dua bentuk negara kesatuan tersebut diatas, negara Republik Indonesia adalah negara kesatuan dengan sistim desentralisasi. Hal ini sesuai dengan ketentuan pasal 18 ayat (1) UUD 1945 yang menyatakan : "Negara Kesatuan Republik Indonesia dibagi atas daerah - daerah provinsi dan daerah provinsi itu dibagi atas kabupaten dan kota, yang tiap - tiap provinsi, kabupaten dan kota itu mrmmpinyai pemerintahan daerah, yang diatur dengan undang- undang" 6 . Oleh karena negara Indonesia itu merupakan suatu 'eenheidstaat' maka Indonesia tidak akan mempunyai daerah dalam lingkungan yang bersifat 'staat' juga. Daerah-daerah itu bersifat autonom (streek dan locale rechtgemeenschappen) atau bersifat administrasi belaka semuanya menurut aturan yang ditetapkan dengan Undangundang . Di daerah-daerah yang bersifat otonom akan diadakan badan perwakilan rakyat daerah, oleh karena itu di daerahpun pemerintahan akan bersendi dasar permusyawaratan" 7 .

Sedangkan prinsip dasar negara kesatuan ialah, yang memegang tampuk kekuasaan tertinggi atas segenap urusan negara adalah Pemerintah Pusat (central Government) tanpa adalah gangguan oleh suatu delegasi atau pelimpahan kekuasaan pada Pemerintah Daerah (Local Government)",

Pendapat diatas menunjukkan bahwa tanggung jawab pelaksanaan tugas-tugas pemerintahan pada dasarnya tetap berada di tangan pemerintah pusat. Akan tetapi karena sistem pemerintah kita sebagai Negara Kesatuan yang didesentralisasikan, maka ada tugas-tugas tertentu yang oleh pemerintah

${ }^{5}$ Josef Riwo Kaho. Prospek Otonomi

Daerah di Negara Kesatuan Republik Indonesia. Rajawali Press.. Jakarta. 1996. h.al. 9

${ }^{6}$ Muh. Kusnardi dan Haemaily Ibrahim. Pengantar Hukum Tata Negara. Fakultas Hukum Universitas Indonesia. Jakarta

${ }^{7}$ Ibid. Hal. 126

${ }^{8}$ Ibid. Hal. 266
Pusat diserahkan sepenuhnya kepada daerah untuk diatur dan diurus sendiri sehingga menimbulkan hubungan timbal balik yang melahirkan adanya hubungan kewenangan dan pengawasan.

\section{B. PERMASALAHAN}

Berdasarkan uraian diatas maka akan nampak berbagai permasalahan yang cukup kompleks untuk dihadapi. Sebagaimana diketahui pelaksanaan otonomi di daerah secara mendasar akan berkisar kepada adanya perencanaan, pelaksanaan, koordinasi dan pengawasan, oleh karenanya dalam tulisan ini akan mengemukakan suatu permasalahan yang perlu mendapat perhatian yang sungguh-sungguh, yaitu "Bagaimanakah Tata Pemerintahan Indonsia Dalam Sistem Otonomi Daerah".

\section{PEMBAHASAN \\ A. Sistem Ketatanegaraan Setelah Amandemen UUD 1945.}

Perubahan UUD 1945 pada Sidang MPR tahun 1999, 2000, 2001 dan terakhir 2002 dapat disebut revolusi ketatanegaraan Indonesia yang dalam bahasa politik disebut reformasi termasuk reformasi pemerintahan daerah.

Perubahan UUD 1945 disebut sebagai revolusi ketatanegaraan karena 74 pasal dalam UUD 1945 sekarang adalah ketentuan baru sama sekali yang memuat 174 ketentuan, sedangkan ketentuan yang lama kurang lebih tersisa 26 ketentuan saja. Dalam ketentuan baru tersebut sangat terlihat bahwa perubahan tidak hanya sebatas menambah atau mengurangi wewenang penyelenggara negara tetapi juga perubahan mendasar peran penyelenggara negara.

Mencermati perubahan UUD 1945 tersebut paling tidak satu hal yang dapat didentifikasi, yaitu perubahan paradigma ketatanegaraan baik dalam arti kelembagaan maupun fungsinya. Pada tingkat daerah terjadi pergeseran kekuasaan antara kepala daerah dengan DPRD mengikuti pergeseran kekuasaan pada tingkat nasional terutama antara Presiden dengan DPR. 
UUD 1945 sebelum diubah jelas memiliki visi dan misi yang berbeda dengan UUD 1945 pasca perubahan. Praktek bernegara selama 32 tahun era Orde Baru menunjukkan kecenderungan kekuasaan terkonsentrasi di tangan Presiden pengendali negara. Secara politis praktis ketika itu Presiden dengan kewenangannya yang maksimal dalam UUD 1945 (16 Pasal dari 37 Pasal mengatur kewenangan Presiden) menjadi yang paling utama atau disebut executive heavy. Kondisi tersebut seterusnya ke tingkat yang lebih rendah gubernur, bupati/walikota bahkan sampai camat/kepala wilayah yang menjadi poros kekuatan pengedali pemerintahan yang disebut sebagai penguasa tunggal.

Reformasi politik kemudian difokuskan pada amandemen UUD 1945 dengan mereduksi kekuasaan Presiden [Pasal 5 ayat (1) Pasal 7 (pembatasan masa jabatan tidak boleh lebih dari 2 kali) sementara kekuasaan membentuk UU yang dulu diatur dalam Pasal 5 ayat (1) sebelumnya dihapus, Pasal 13 (pengangkatan duta, dan menerima serta penempatan duta negara lain memperhatikan pertimbangan DPR), Pasal 14 ayat (1) (memberi grasi dan rehabilitasi memperhatikan pertimbangan MA), Pasal 14 ayat (2) (pemberian amnesti dan abolisi memperhatikan pertimbangan DPR), Pasal 15 (pemberian gelar, tanda jasa dan tanda kehormatan lainnya diatur dengan UU), Pasal 20 (DPR memegang kekuasaan membentuk UU). Dapat disimpulkan bahwa semangat perubahan pertama adalah mereduksi kekuasaan presiden dan penguatan fungsi DPR (empowering parliament) melalui perubahan Pasal 20 yang menempatkan DPR sebagai pemegang kekuasaan pembentuk UU.

Eksistensi MPR sebelum UUD 1945 diubah sebagai lembaga tertinggi negara. Dengan posisi itu seolah-olah MPR menjadi institusi atasan dari semua lembaga tinggi negara yang ada (Presiden, DPR, MA, DPA, dan BPK). Meskipun dalam aktivitasnya lebih merupakan justifikasi dari keinginan tunggal Presiden ketika itu. Oleh karena itu dalam perubahan ketiga fungsi MPR direduksi pula dengan tidak lagi memposisikan MPR sebagai pelaku tunggal kedaulatan rakyat.

$$
\text { Setelah perubahan, seperti }
$$

dirumuskan dalam Pasal 1 ayat (2)

Kedaulatan berada di tangan rakyat dan dilaksanakan menurut Undang-Undang Dasar. Susutnya peran MPR tersebut tentu saja perlu tranformasi kelembagaan untuk mengambil alih peran tertentu MPR yang tidak boleh dihilangkan.

Pergeseran kewenangan Presiden di satu sisi, penguatan fungsi DPR pada sisi lain dan reduksi wewenang MPR pada sisi lain lagi mencerminkan beralihnya sistem pemerintahan yang sebelumnya condong parlementer (MPR) ke presidensil murni ${ }^{1} 8$. Meskipun dalam praktek dewasa ini masih ada ciri parlementer.

Perubahan sistem pemerintahan di tingkat pusat tercermin pula di tingkat daerah yang ditandai oleh pilkada secara langsung. Kalau dibandingkan sistem politik tingkat pusat dengan daerah setidaknya dapat diklasifikasikan sebagai berikut:

Pemerintah Nasional:

Tidak lagi dikenal superbody, tidak ada lagi lembaga menerima pertanggungjawaban lembaga lainnya.

Sistem presidensial murni

Sistem pemisahan kekuasaan

Anggota Badan Legeslatif (DPR dan

DPD) dipilih langsung: anggota DPR dicalonkan oleh Parpol, DPD mencalonkan diri secara perorangan, meskipun ada yang memanfaatkan Parpol sebagai agen dalam kampanye sekaligus jaringan pendukung.

Presiden dan Wakil Presiden dipilih langsung dan dicalonkan oleh parpol peserta Pemilu.

Pemerintah Daerah (Provinsi,

Kabupaten/Kota)

Lembaga pemerintahan (Kepala daerah dan DPRD) sederajat

Tidak saling tergantung

Tidak saling intervensi kecuali dalam rangka fungsi membahas raperda dan pengawasan menurut mekanisme yang ditentukan

Anggota DPRD dipilih langsung

Gubernur/Bupati/Walikota dipilih langsung 


\section{B. Otonomi dan Tata Pemerintahan Daerah}

Perubahan pasal 18 ditambah dengan 18A dan Pasal 18B UUD 1945 menjelaskan kepada semua elemen negara bahwa ketatanegaraan di tingkat daerah berubah. Perubahan dimaksud seperti pada Pasal 18 ayat (1) NKRI dibagi atas daerah-daerah provinsi dan daerah provinsi dibagi atas kabupaten dan kota, yang tiap-tiap provinsi, kabupaten, dan kota itu mempunyai pemerintahan daerah, yang diatur dengan UU. Masing pemerintahan daerah baik provinsi, daerah kabupaten maupun kota mengatur dan mengurus sendiri urusan pemerintahan menurut asas otonomi dan tugas pembantuan [Pasal 18 ayat (2)] jo ayat (6).

Mengatur dan mengurus sendiri urusan pemerintahan itu diselenggarakan berdasarkan prinsip otonomi seluas-luasnya [Pasal 18 ayat (5)]. Dalam pengaturan lebih lanjut banyak kalangan menafsirkan otonomi seluas-luasnya lebih menjurus pada sistem federalisme. Terlepas dari pandangan tersebut harus ditegaskan bahwa pengaturan lebih lanjut dalam undang-undang adalah soal pilihan tafsir legislator nasional.

Mengurus sendiri dalam kontek sistem otonomi yang dianut sampai sekarang adalah otonomi mengatur dan otonomi melaksanakan pemerintahan. Oleh karena kewajiban mengatur sendiri sangat fundamental, maka diperlukan legislatif daerah (DPRD) di masing-masing pemerintahan daerah yang anggotanya dipilih oleh warga daerah secara langsung bersamaan dalam Pemilu legislatif nasional.

Untuk melaksanakan aturan yang dibuat sendiri diperlukan eksekutif daerah yang dipimpin kepala daerah baik provinsi, kabupaten maupun kota [Pasal 18 ayat (3)]. Selain melaksanakan aturan yang dibuat sendiri (Perda dan Peraturan Kepala Daerah) juga melaksanakan aturan pusat (UU, PP dan Perpres).

Sejak 2004 kepala pemerintahan daerah provinsi (Gubernur) kabupaten (Bupati) dan Walikota (Kota) dipilih secara langsung. Cara pemilihan ini sebenarnya sebagai mengikuti perubahan ketatanegaraan pada tingkat pemerintahan nasional di mana jabatan presiden diisi melalui pemilihan secara langsung.

Pemilihan kepala daerah secara langsung (Pemilukada) memberi isyarat bahwa hubungan legislatif daerah dengan kepala daerah terselenggara berdasarkan prinsip kesimbangan yang bersumber pada perolehan otoritas melalui pemilihan langsung yang berbeda. Sistem pemilihan yang berbeda demikian semestinya diikuti oleh sistem perimbangan kekuasaan (cheks and balancies) di mana mestinya masingmasing memiliki kekuasaan yang saling mengimbangi. Fenomena sekarang ini kebanyakan kepala daerah memiliki kekuasaan masih lebih besar ketimbang kekuasaan DPRD.

Sebenarnya ide kemandirian DPRD dalam membentuk Perda, pengawasan terhadap pelaksanaan Perda termasuk pengawasan terhadap pengejawantahan Perda dalam Peraturan Kepala Daerah dan pemakzulan kepala daerah sudah sangat tepat memposisikan DPRD sebagai penyeimbang kekuasaan kepala daerah. Berdasarkan prinsip keseimbangan tersebut, maka panggung politik di daerah dengan sendirinya tidak lagi berada di bawah kekuatan tunggal kepala daerah. Kepala daerah sebagai kreasi Pemilukada adalah mewakili kekuatan politik warga daerah yang memilihnya, sedangkan DPRD adalah kreasi pemilu yang anggotanya dipilih langsung oleh warga daerah berdasarkan prinsip suara terbanyak ${ }^{18}$.

Desentralisasi dan otonomi dalam kajian ilmiah demokrasi liberal memiliki keunggulan $^{19}$ sekaligus konsekuensi kebebasan dalam mengejawantahkan otonomi, lebih lagi dalam pengertian otonomi seluas-luasnya. Keunggulan dimaksud menjadi harapan bagi daerah untuk memberdayakan diri di bawah payung

\section{$\mathrm{VI} / 2008$ \\ 18 Putusan MK No.22-24/PUU- ${ }^{19}$ Zen Zanibar. Op.Cit.}


negara kesatuan, sebaliknya konsekuensi kebebasan dapat dinetralisir melalui aturan yang ketat tanpa mengurangi makna otonomi itu sendiri.

Ide otonomi seluas-luasnya diamanatkan oleh UUD 1945 mengisyaratkan bahwa daerah mengatur sendiri, melaksanakan sendiri segala urusan daerah dan menentukan pemimpin sendiri. Adapun pemerintah nasional mengatur melalui undang-undang apa saja yang menjadi wewenang daerah dan bagaimana wewenang dimaksud diselenggarakan. Faktanya adalah pengaturan politik yang terpusat dan seragam, sehingga perpolitikan di panggung nasional turun ke daerah, meskipun dalam kadar berbeda.

Parpol di daerah adalah "anak pungut" parpol nasional, politisi parpol nasional sebagian besar memang produksi panggung politik nasional yang secara substansial memiliki kadar jauh melebihi politisi lokal. Politisi lokal umumnya lahir bukan melalui proses rekrutmen normal sebagaimana mestinya dilakukan oleh menejemen parpol yang sehat. Mereka direkrut sekedar perpanjangan tangan elit pusat untuk mempromosikan parpol. Akibatnya DPRD diisi oleh kalangan yang masih sangat belia dalam berpolitik, bahkan belum memiliki pengetahuan yang memadai untuk menjalankan peran sebagai legislator lokal. Oleh karena itu di beberapa daerah DPRD tidak memiliki posisi tawar terhadap kepala daerah. Seperti dapat disaksikan di sebagian besar kabupaten/kota sentrum kewibawaan publik masih pada kepala daerah. Lagi pula secara administratif dan protokuler jabatan kepala daerah melebihi jabatan publik lainnya. Tidak heran warisan lama yang bernama muspida dan prilaku penguasa tunggal acapkali muncul.

Berjalan seiring dengan kondisi tersebut perbedaan pemilihan antara kepala daerah anggota DPRD, seperti telah dikemukakan sebelumnya, juga menjadi faktor ketidaksehatan politik di daerah. Pemilihan yang berbeda kedua lembaga publik daerah tersebut mencerminkan perbedaan kepentingan politik dalam menentukan kebijakan, terutama yang berkaitan dengan pelayanan publik dengan kepentingan politik DPRD. Perbedaan terjadi karena seorang memilih calon legislatif belum tentu kerena alasan ideologi partai kendaraan calon. Sangat mungkin seseorang memilih karena faktor personal yang tidak bisa dimengerti. Demikian pula seorang pemilih memilih calon dalam Pemilukada sangat mungkin tidak ada hubungan dengan parpol pendukungnya.

Perbedaan tersebut dalam prakteknya sangat berpengaruh dalam hubungan DPRD dengan kepala daerah. Di beberapa daerah hubungan kedua lembaga tersebut cenderung tidak harmonis dalam arti seringkali berbeda dalam mengadapi persoalan tertentu. Program-program kepala daerah tidak mendapat dukungan DPRD yang dicerminkan dalam bentuk penolakan atau memperlambat pembahasan usulan kepala daerah. Sebaliknya program-program legislatif tidak mendapat respon positif dari kepala daerah karena kepala daerah merasa tidak ada kepentingan dengan ide-ide DPRD.

Ketegangan antara kepala daerah dan DPRD beberapa tahun terakhir terjadi di berbagai daerah di Indonesia. Ketegangan terutama bersumber dari ketidaktergantungan kepala daerah terhadap DPRD. Di salah satu kabupaten kepala daerah dalam pemilukada diusung oleh partai-partai kecil, sementara calon dari partai besar tersingkir. Dalam perjalanan legislatif dan eksekutif berseberangan. DPRD yang dikendalikan parpol besar, sementara kepala daerah merasa tidak ada hubungan dengan parpol besar. Di sejumlah kabupaten kepala daerah memanfaatkan isu korupsi yang dituduhkan kepada sejumlah anggota DPRD sebagai alat untuk melemahkan institusi DPRD dengan tujuan agar semua ide-ide kepala daerah didukung oleh DPRD. Di suatu kabupaten kebijakan-kebijakan kepala daerah terus menerus dilawan oleh DPRD karena dukungan partai kepala daerah di DPRD lemah, sehingga setiapkali kepala daerah menginginkan dukungan perlu pendekatan khusus. Di suatu provinsi DPRD sejalan seiring dengan kepala daerah, padahal 
kekuatan parpol pendukung kepala daerah lemah di DPRD. Namun karena sebagian besar anggota DPRD "diakomodasi" oleh eksekutif, maka hampir tidak pernah ada ideide kepala daerah yang dikritisi oleh DPRD. Dengan demikian sistem pemilihan yang berbeda antara kedua lembaga politik daerah dewasa ini, seperti diungkapkan LSI, menghasilkan pemerintahan daerah yang kebanyakan terbelah (Devided Government). Meskipun beberapa bersatu (unifided government)

Penyelenggaraan otonomi daerah di Indonesia direfleksikan oleh banyaknya inkonsistensi pemerintah pusat. Hal ini mengindikasikan belum siapnya pemerintah pusat untuk merubah paradigma pemerintahan yang sentralistik ke arah pemerintahan yang desentralistik. Inkonsistensi pemerintah pusat terjadi dalam dua hal, yaitu secara vertikal dan secara horizontal. Secara vertikal inkonsistensi ini dicerminkan oleh berbagai produk peraturan perundang-undangan yang tidak harmonis dan tidak sinkron. Seringkali ketentuan pengaturan di dalam Peraturan Pemerintah mereduksi isi Undang-Undang tentang Pemerintahan Daerah. Pada sisi lainnya, berbagai macam peraturan perundangundangan seringkali mengalami perubahan yang sangat cepat dan tidak memperhatikan kemampuan daerah dalam implementasinya. 20

Inkonsistensi secara horizontal dapat dilihat dari tidak harmonisnya ketentuan peraturan perundang-undangan antar satu sektor dengan sektor lainnya. Bahkan sebagian aparatur penyelenggara negara di Kementrian dan Lembaga Pemerintah Non Departemen masih memiliki paradigma dan pemikiran yang sentralistik. Hal ini misalnya direfleksikan dengan semakin banyaknya Unit Pelaksana Teknis (UPT), Balai-Balai, dan Kantor-Kantor Regional dari Kementian dan Lembaga Pemerintah Non Departemen di daerah. Tujuan didirikannya berbagai

\footnotetext{
${ }^{20}$ Eko Prasojo. Makalah Disampaikan Pada Lokakarya dan Pra Seminar Nasioanl Otonomi Daerah. Universitas Palembang. 10 Januari 2009.
}

lembaga teknis pusat di daerah sebenarnya merupakan kegamangan dan ketidakrelaan sektor di pusat terhadap kewenangan yang sudah diserahkan kepada pemerintahan daerah. Pada sisi lainnya harus diakui, bahwa ketiadaan perangkat dekonsentrasi di tingkat kabupaten/kota telah menyebabkan sulitnya koordinasi antara pemerintah pusat dan pemerintah. Gubernur sebagai wakil pemerintah pusat di daerah tidak memiliki perangkat dekonsentrasi untuk menjalankan peran dan fungsinya tersebut. Kedua hal ini ketidakrelaan sektor di pusat terhadap kewenangan yang diserahkan kepada daerah dan ketiadaan perangkat dekonsentrasi- telah menyebabkan berbagai inkonsistensi dalam praktek penyelenggaraan otonomi daerah.

Dari perspektif daerah, otonomi diwarnai oleh inkompetensi pemerintahan daerah untuk menyelenggarakan urusan yang telah diserahkan. Demikian banyaknya urusan yang diserahkan, tidak diikuti dengan kemampuan Sumber Daya Manusia yang memadai. Hal ini dipersulit dengan munculnya semangat kedaerahan, sehingga di sejumlah daerah terjadi overstaff (kelebihan pegawai), sedangkan di daerahdaerah lain terjadi understaff (kekurangan pegawai). Kondisi ini menyulitkan impelementasi otonomi daerah, karena pada sebagian daerah terjadi kekurangan sumber daya manusia, pada sebagian daerah yang lain terjadi kelebihan sumber daya manusia.

Dalam pemerintahan daerah, hal ini menyebabkan terjadinya fragmented administration yang berlebihan dan uncoordinated development. Para Bupati dan Walikota lupa, bahwa dalam kapasitasnya sebagai wakil pemerintah pusat di daerah, Gubernur tetap memiliki kewenangan untuk melakukan pengawasan dan koordinasi terhadap pelaksanaan kewenangan oleh Kabupaten/Kota. Tidak mengherankan jika beberapa Visi, Misi dan Rencana Strategis di tingkat Nasional tidak dapat dicapai pada tingkat kabupaten/kota. Hal ini disebabkan lemahnya peran Gubernur sebagai Wakil Pemerintah Pusat untuk melakukan koordinasi dan pembangunan yang dilakukan oleh Kabupaten/Kota. Sebaliknya, sektor- 
sektor di tingkat pusat (Departemen dan Lembaga Pemerintah Non Departemen) tidak memiliki lagi Kantor Departemen di tingkat Kabupaten/Kota. Akumulasi lemahnya peran Gubernur sebagai Wakil Pemerintah Pusat dan ketiadaan Kantor Departemen ini telah menyumbangkan terjadinya beberapa beberapa masalah nasional seperti busung lapar, polio, kelangkaan pupuk, dan buruknya kualitas pendidikan dan kesehatan.

Otonomi daerah dengan desain yang sekarang berlaku, sangat berpotensi untuk menyebarluaskan terjadinya korupsi di daerah. BPK menemukan banyak aset dekonsentrasi yang tidak jelas perrtangungjawabannya. Hal ini terjadi karena kewenangan dan keuangan yang sudah diserahkan oleh pemerintah pusat kepada pemerintahan daerah tidak dapat diawasi secara akuntabel penggunaannya. Dapat dikatakan, bahwa dana dekonsentrasi dan dana tugas pembantuan sangat sulit untuk diawasi penggunaannya. Dana-dana dekonsentrasi adalah dana yang dimiliki dan dianggarkan oleh sektor-sektor di tingkat untuk pembangunan di daerah.

Tarik ulur kepentingan atas kewenangan dan keuangan yang terjadi antara pusat dan daerah, terefleksi dalam penyelenggaraan azas dekonsentrasi yang lebih dominan ketimbang azas desentralisasi. Meskipun sejumlah besar kewenangan (atau disebut juga urusan) telah diserahkan kepada daerah, tetapi sejumlah sektor di pusat seakan tidak rela melepaskan kewenangan tersebut, karena hal ini berarti pula melepaskan sumber-sumber keuangan yang dimilikinya. Beberapa sektor bahkan mungkin tidak menyadari atau mengetahui telah terjadi perubahan yang radikal dalam penyelenggaraan pemerintahan dan pembangunan. $^{21}$

C. Hubungan Kepala Daerah dan DPRD

Hubungan antara Kepala Daerah dan DPRD dalam prakteknya sering telah menyebabkan lemahnya fungsi-fungsi yang harus dilakukan oleh DPRD. Setelah kepala daerah dipilih langsung oleh masyarakat,

\footnotetext{
${ }^{21}$ Eko Prasojo. Ibid.
}

maka kepala daerah memiliki legitimasi yang sangat kuat. Bahkan demikian kuatnya, kepala daerah tidak bertanggungjawab kepada DPRD. Pelemahan fungsi DPRD ini terjadi karena meletakkan kepala daerah sebagai titik berat dalam penyelenggaraan pemerintahan daerah (Eexcutive Heavy). Sedangkan DPRD, meskipun dipilih secara langsung oleh masyarakat memiliki fungsifungsi yang sangat lemah. Misalnya saja fungsi pengawasan tidak dapat dilakukan secara efektif karena pada akhirnya dewan tidak melakukan tekanan kepada kepala daerah atas hasil temuan pengawasan. Sedangkan fungsi pengganggaran tidak berjalan efektif karena DPRD hanya memiliki akses yang terbatas atas rencana anggaran yang diusulkan dan data-data yang dijadikan sebagai asumsi dalam penyusunan anggaran.

Ketidakjelasan hubungan antara kepala daerah dan DPRD ini telah menyebabkan pekerjaan dan kinerja kepala daerah yang tidak terkontrol. Dalam sistem pemilihan langsung kepala daerah, sejatinya masyarakat diharapkan dapat melakukan kontrol atas kinerja kepala daerah. Dalam praktek di Indonesia hal ini tidak terjadi karena masyarakat kurang memiliki kesadaran, pengetahuan, koompetensi dan jaringan yang kuat untuk melakukan kontrol atas pekerjaan dan kinerja kepala daerah. Pada sisi lainnya DPRD sebagai wakil rakyat tidak dapat melakukan fungsinya secara baik karena lemahnya kedudukan yang dimilikinya. Kepala daerah bertanggungjawab kepada pemerintah pusat dan memberikan keterangan laporan pertanggungjawaban kepada DPRD. Keterangan laporan pertanggungjawaban ini menempatkan DPRD dalam fungsi wakil rakyat yang sangat lemah karena tidak memiliki efek pertanggungjawaban kepala daerah yang maksimal. Sedangkan pemerintah pusat dalam prakteknya tidak melakukan pengawasan secara efektif baik dalam pengawasan hukum terhadap Perda maupun pengawasan atas hasil-hasil pembangunan. Masyarakat sebagai pengawasan sosial juga tidak dapat 
melakukan fungsinya secara baik. Satusatunya pengawasan yang masih berjalan efektif terhadap penyelenggara pemerintahan daerah adalah pengawasan fungsional yang dilakukan oleh BPKP dan BPK. Dengan kata lain, praktek penyelenggaraan pemerintahan daerah selama ini tidak dapat dikontrol secara baik oleh DPRD. Pertanyaan yang harus diajukan adalah kepada siapa kepala daerah harus akuntabel? Apakah kepada pemerintah pusat, ataukah kepada DPRD ataukah kepada masyarakat. Pertanyaan ini harus dijawab secara rinci dan jelas dalam Peraturan Perundanng-undang Pemerintahan Daerah.

\section{P $\quad \mathbf{E} \quad \mathbf{N} \quad \mathbf{U} \quad \mathbf{T} \quad \mathbf{U} \quad \mathbf{P}$}

Berdasarkan uraian-uraian yang telah diuraikan diatas, maka dapat menarik kesimpulan dan saran-saran sebagai berikut : a. Kesimpulan

1. Sistem Otonomi Daerah telah memberikan landasan strategis bagi terwujudnya penyelenggaraan otonomi daerah yang luas, nyata dan bertanggung jawab berada didaerah Kabupaten dan Kota yang didukung pula oleh adanya perimbangan keuangan secara proporsional antara pusat dan daerah.

Kewenangan Pemerintah Pusat hanya melakukan pembinaan yang menekankan pada fasilitas dalam upaya memperdayakan daerah otonom, melalui pemberian pedoman, bimbingan, pelatihan dan pengawasan yang bersifat represif untuk memberi kebebasan kepada daerah otonom dalam berkreasi untuk menyelenggarakan pemerintahannya dan pengambilan keputusan yang sesuai dengan kondisi daerahnya terutama kebijakan yang harus cepat ditangani pelaksanaannya.

2. Sistem ketatanegaraan dewasa ini tidak lagi homogin dan tunggal seperti dulu. Desentralisasi dengan otonomi seluasluasnya sudah hadir dengan berbagai konsekuensi dalam tafsir berbeda-beda. Desentralisasi dan otonomi seluas-luasnya sasarannya adalah untuk keadidayaan nasional. Keadidayaan nasional tergantung kepada keberdayaan daerah. Dalam kerangka itu perlu direnungkan dalam-dalam bahwa kesempatan kita belajar demokrasi sudah sangat sempit, globalisasi adalah tantangan di depan mata. Kalau tata pemerintahan belum juga beres dan politisi berebut posisi sementara, maka kita akan semakin tertinggal dari negara-negara lain.

b. Saran- Saran

Pemikiran dan konstruksi tentang asas dekonsentrasi dalam penyelenggaraan pemerintahan harus diarahkan pada keseimbangan untuk menciptakan efisiensi/efektivitas pembangunan. Fragmentasi dan tidak terkoordinirnya pemerintah dapat menyebabkan gagalnya pembangunan secara nasional. Karena itu didiusulkan beberapa alternatif kebijakan yang dapat diambil : Pertama, Gubernur sebagai wakil pemerintah pusat di daerah harus menjadi perekat antara pemerintah pusat dan pemerintah daerah. Dalam hal ini fungsi pengawasan, pembinaan dan koordinasi harus dilakukan secara optimal oleh para gubernur terhadap kabupaten/kota diwilayahnya, oleh karenanya perlu perlu digagas perangkat dekonsentrasi gubernur yang bersifat fungsional bukan structural. Kedua, kebijakan yang memfokuskan dan memperkuat asas dekonsentrasi dalam penyelenggaraan pemerintahan sehingga dana-dana dekonsentrasi dapat digunakan dengan tepat sasaran. Strategi ini sejalan dengan dengan penguatan otonomi daerah. Ketiga, adalah membentuk kembali instansi vertikal di kabupaten/kota, agar penyelenggaraan pemerintahan daerah dapat berjalan selaras dan seimbang.

Dalam rangka pelaksanaan otonomi daerah diperlukan mengubah pola pikir segenap birokrasi Pemerintah dari orientasi kewenangan menjadi orientasi pelayanan dan pengayoman kepada masyarakat serta organisasi pemerintahan untuk mewujudkan pemerintahan yang bersih berwibawa, modern, transparan dan profesional.

Dengan diberlakukannya otonomi daerah, diharapkan pemerintahan daerah benar-benar memperhatikan hak dan kewajiban daerah otonom. Hendaklah otonomi daerah itu lebih merupakan kewajiban daripada hak, yaitu kewajiban 
daerah untuk ikut serta melancarkan jalannya pembangunan sebagai sarana untuk mencapai kesejahteraan rakyat yang harus diterima dan dilaksanakan dengan penuh rasa tanggung jawab.

Selain itu dalam menyelenggarakan otonomi daerah hendaklah unsur koordinasi antara instansi-instansi pemerintah daerah harus mendapat perhatian yang khusus, hingga dalam menyelenggarakan pemerintahan di daerah dapat berjalan dengan serasi selaras dan seimbang sebagaimana yang diharapkan.

\section{DAFTAR PUSTAKA}

Abu Daud Busroh. Sistem Pemerintahan Republik Indonesia., Bina Aksara. Jakarta. 1989.

Amrah Muslimin., Aspek - Aspek Otonomi Daerah. Alumni Bandung. 1978

Beberapa Azas Dan Pengertian Pokok Tentang Administrasi Dan Hukum Administras. Alumni Bandung. 1985

Abdurahman. Beberapa Pemikiran Tentang Otonomi Daerah. Media Sarana Press. Jakarta. 1987.

Eko Prasojo. Politik Hukum dan Tata Pemerintahan Dalam Otonomi Daerah. Makalah sisampaikan pada Lokakarya dan Pra Seminar Nasional Otonomi Daerah. Universitas Palembang. 10 Januari 2009.

Miriam Budiardjo. Dasar - Dasar Ilmu Politik. PT. Gramedia. Jakarta.. 1989.

M. Kusnardi dan Harmaily Ibrahim. Pengantar Hukum Tata Nagara. Pusat Studi Hukum Tata Negara FH. Univ. Indonesia. Jakarta. 1980.

Solly Lubis., Pergeseran Garis Politik Dan Perundang-undangan Mengenai Pemerintahan Daerah. Alumni. Bandung. 1987.

Ni'matul Huda. Hukum Tata Negara Indonesia. PT. Rajagrafindo Persada. Jakarta. 2005
Sunindhiah., Praktek Penyelenggaraan Pemerintahan Di Daerah. Bina Aksara. Jakarta. 1987

Suparmi Pamudji. Pelaksanaan Azas Desentralisasi Dan Otonomi Daerah Di Dalam Sistem Administrasi Negara Kesatuan RI. Karya Dharma. Jakarta, 1984.

Sarundajana. Pemerintahan Daerah. Pustaka Sinar Harapan. Jakarta. 1997.

Titik Triwulantutik. Pokok-Pokok Hukum Tata Negara Indonesia. Prestasi Pustaka. Jakarta. 2005.

Sentosa Sembiring. Himpunan Lengkap Undang-Undang Tentang Pemerintahan Daerah/UndangUndang Nomor 32 Tahun 2004 Tentang Pemerintahan Daerah. Nuansa Aulia. Jakarta. 2006.

Zen Zanibar. Politik Hukum dan Tata Pemerintahan Dalam Otonomi Daerah. Makalah sisampaikan pada Lokakarya dan Pra Seminar Nasional Otonomi Daerah. Universitas Palembang. 10 Januari 2009. 